\title{
Differences in Expression of Peroxisome Proliferator-activated Receptor-y in Early-onset Preeclampsia and Late-onset Preeclampsia
}

\section{Wiryawan Permadi}

Universitas Padjadjaran

Kemala Mantilidewi ( $\nabla$ kmantilidewi@gmail.com )

https://orcid.org/0000-0003-4588-8018

Astrid Feinisa Khairani

Universitas Padjadjaran

Uci Ary Lantika

Universitas Islam Bandung Fakultas Kedokteran

Ayu Angelina Ronosulistyo

Universitas Padjadjaran

Hartanto Bayuaji

Universitas Padjadjaran

\section{Research note}

Keywords: PPAR-y, early onset preeclampsia, late-onset preeclampsia, trophoblast, placenta

Posted Date: March 16th, 2020

DOI: https://doi.org/10.21203/rs.2.21591/v2

License: (c) (i) This work is licensed under a Creative Commons Attribution 4.0 International License.

Read Full License

Version of Record: A version of this preprint was published at BMC Research Notes on March 27th, 2020. See the published version at https://doi.org/10.1186/s13104-020-05029-x. 


\section{Abstract}

Objective: Preeclampsia is a leading cause of maternal and fetal morbidity and mortality. Peroxisome Proliferator-activated Receptor-y (PPAR- $\gamma$ ) has been reported to be implicated in key functions in cell that were also important to ensure normal pregnancy development. In this study, we conducted primary culture of trophoblastic cells from normal pregnant women in the third trimester $(n=3)$, and from patients with EOPE $(n=3)$, and LOPE $(n=3)$. Expression of PPAR- $y$ was determined by Western Blot. Data are the means $\pm S$.E. from three separate experiments. Statistical analysis was performed by SPSS software,version 20.0, a $p<0.05$ was considered significant (one-way ANOVA and Bonferroni's test) versus normal serum pregnancy. Results: Serum from normal pregnant women and those with EOPE did not induce any difference in the expression of PPAR- $y$ ( $p>0.05)$. In contrast, expression of PPAR- $y$ was increased in those cells with serum from LOPE $(p<0.001)$. Therefore, we conclude that hypothetically PPAR-y might play role in the pathophysiology of LOPE but not in EOPE. Other possibility is the activity of PPAR- $y$ in EOPE is inversely correlated with the expression, therefore the high enzymatic activity of PPAR$Y$ is tightly regulated by attenuating its expression.

\section{Introduction}

Pre-eclampsia is defined as a hypertensive disorder related to pregnancy, and included among the most common medical complications of pregnancy. It carries burden around the world, causing a high maternal and perinatal mortality and morbidity.(1-2) The mechanisms involve in the genesis of this syndrome is not well understood, although several factors has been extensively well studied, such as defective placentation(3-6), ischemia of the uteroplacental circulation (5,7-9), endothelial cell dysfunction(10-11), and excessive inflammatory reactions to the invading trophoblast(12-13).

Classification of preeclampsia may be divided into two distinct entities, early- and late-onset. The earlyonset preeclampsia (EOPE) occurs at $<34$ weeks of gestational age, and the late onset preeclampsia (LOPE), is those preeclampsia of which manifestation present at $\geq 34$ weeks of pregnancy.(14-16) Both EOPE and LOPE have been found to be associated with different biochemical markers, genetic and environmental risk factors, prognosis, heritability, and clinical features. Evidences showed that several of the markers rising prior to pregnancies, and may persisted or disappeared before clinical manifestation of preeclampsia.(17-19)

Peroxisome Proliferator-activated Receptor- $\gamma$ (PPAR- $\gamma$ ) is a member of the nuclear receptor superfamily and has been reported to be implicated in key functions in the cells including cell proliferation and differentiation, inflammation and oxidation, glucose and lipid metabolism. These functions were also important to ensure normal pregnancy development.(20-21) In normal pregnancy, activators of PPAR- $y$ was increased along with increasing gestational age. In a previous study that compared JEG-3 cell lines treated with serum extract from women with normal pregnancy and mild, severe early-onset, and severe late-onset preeclampsia, Waite et al demonstrated that PPARy activators was reduced by $60 \%$ in the sera

of severe early onset and by $55 \%$ in severe late onset preeclampsia compared to normal serum (22). They 
defined severe preeclampsia as proteinuria $>5 \mathrm{~g}$ in 24 hours, as well as one of the following characteristics: an absolute blood pressure reading of $>160 \mathrm{~mm} / \mathrm{Hg}$ systolic or $110 \mathrm{mmHg}$ diastolic; platelet count $<140.000 / \mathrm{ml}$, or liver function test results of 1.5 times the normal range. The same study reported no significant difference in cells treated with serum from mild preeclamptic patients compared to normal pregnancy (22). In contrast, Holdsworth-Carson et al.(23) examined placental expression of PPAR- $y$ and demonstrated that placentas from women with pre-clampsia did not demonstrate any differences in mRNA or protein expression of PPAR-y compared with healthy controls.

As previously mentioned, there seemed to be distinct biological mechanisms underlying EOPE and LOPE. Compounded with the result of Waite et al, we suspect there may be differences in PPARY expression in EOPE and LOPE placentas which may elucidate the differences in mechanisms between the two. However, to date, there are currently insufficient evidence to suggest how the expression of PPARY may differ in EOPE and LOPE compared to normal pregnancy. Therefore, here we attempted to study the possible involvement of PPAR- $\gamma$ in EOPE, LOPE compared to that of normal pregnancy.

\section{Methods}

\section{Cells}

Our cellular model of preeclampsia, using primary trophoblastic cells derived from normal pregnancy incubated in sera of preeclamptic women was based on the work of Pramatirta et al (dissertation, unpublished data), which in turn was based on the work of Neale et al (24). Neale et al demonstrated that trophoblast $(\mathrm{H} 8)$ cell line treated with sera of preeclamptic patients exhibited decreased cell viability compared to cells treated with sera from normal pregnancy. Therefore, in our study, each cultured cell was meant to represent cellular models of normal, early-onset, and late-onset preeclampsia (24).

Cultured of primary trophoblastic cells obtained from term normal pregnancy was courtesy from Oncology and Stem Cell Working Group, Faculty of Medicine, Universitas Padjadjaran, Bandung, Indonesia. Cells were maintained in medium amniomax basal media (Gibco USA) added with amniomax supplement (Gibco, USA), at $37^{\circ} \mathrm{C} / 5 \% \mathrm{CO}_{2}$.

\section{Maternal serum}

Serum was courtesy from Oncology and Stem Cell Working Group, Faculty of Medicine, Universitas Padjadjaran, Bandung, Indonesia. Serum were obtained from normal pregnant women in the third trimester $(n=3)$, and from patients with $\operatorname{EOPE}(n=3)$, and LOPE $(n=3)$. Pregnancies were considered normal when patients did not have medical and obstetric complications of pregnancy and delivered aterm neonate ( $\geq 37$ weeks) who was appropriate for gestational age. Preeclampsia was defined as hypertension (systolic blood pressure $\geq 140 \mathrm{mmHg}$ or diastolic blood pressure $\geq 90 \mathrm{mmHg}$ on at least two occasions, $4 \mathrm{~h}$ to 1 week apart) and proteinuria (300 mg in a 24-h urine collection or one dipstick measurement of $>2+)(24-25)$. Patients with severe features, chronic hypertension, diabetes mellitus, 
systemic diseases such as antiphospholipid antibody syndrome, thrombophilia or transient blood pressure elevations were excluded from this study.

\section{Exposure Cells to Serum}

Cells were plated at 24 -well and incubated for $24 \mathrm{~h}$ at $37^{\circ} \mathrm{C}$ with $5 \% \mathrm{CO}_{2}$. The cells were followed by treatment with serum from the patients at $15 \%$ final concentration(24-26) in amniomax (Gibco USA) in the presence of amniomax supplement (Gibco, USA) for $24 \mathrm{~h}$. The three groups were as follow: normal serum (normal), EOPE, and LOPE.

\section{Whole Cell Lysate Preparation and Western Blotting}

Cells were washed with ice-cold 1x PBS and then lysed in RIPA buffer in the presence of protease inhibitors and phosphatase inhibitors. Lysates were then added with SDS sample buffer ( $50 \mathrm{mM}$ Tris-HCl $\mathrm{pH}$ 8.0, $150 \mathrm{mM} \mathrm{NaCl}, 1 \mathrm{mM}$ EDTA,1\% SDS), and were centrifuged at 17,500 $\mathrm{Xg}$ for $20 \mathrm{~min}$ at room temperature. The resulting supernatants with equal amount of total protein was loaded in each lane. After transfer to PVDF, the membranes were blocked with $0,25 \%$ BSA in TBS-Tween for 30 minutes at room temperature. Primary and secondary antibody incubations at $4^{\circ} \mathrm{C}$ overnight, and 90 minutes at room temperature, respectively, with antibodies diluted in blocking buffer BSA 0,1\%. Antibodies used included rabbit monoclonal antibody (mAb) against PPAR-y (Cell Signaling Technology), mouse anti-actin mAb (Thermo Fisher Scientific), HRP-conjugated secondary antibodies against anti-rabbit, and anti-mouse was from Thermo Fisher Scientific and Santa Cruz, respectively. After treatment with ECL reagent (GE Healthcare), proteins in membranes were detected by C-Digit (Licor). Expression was quantified by densitometric scanning by Image-J followed by normalizing PPAR-y expression to that of $\beta$-actin.

\section{Statistical Analysis}

Data are the means \pm S.E. from three separate experiments. Statistical analysis was performed by SPSS software, version 20.0 (SPSS Inc., Chicago), a $p<0.05$ was considered significant (one-way ANOVA and Bonferroni's test) versus serum normal pregnancy.

\section{Results}

We attempted to study the possible involvement of PPAR-y in EOPE, LOPE compared to that of normal pregnancy. The result of incubation of primary trophoblastic cells with serum of normal pregnancy, serum of EOPE, and LOPE, analyzed by Western Blot shown as follow in Figure 1.

Our result showed the expression of PPAR-y in primary trophoblastic cells treated by serum normal pregnancy compared to that of EOPE showed no expression in Western Blot. Remarkably, treatment of LOPE showed marked expression of PPAR-y compared to that of normal pregnancy.

Next, we confirmed the significance of our result. We performed quantification and showed the result in Figure 2. The result was there was no difference in the expression of PPAR- $y$ in those cells treated by 
EOPE compared to normal pregnancy $(p<0.01)$, while the treatment of LOPE resulted in significant high expression of PPAR- $\gamma$ compared to that of normal pregnancy $(p<0.001)$.

\section{Discussion}

In our experiment, we used a primary trophoblastic cells obtained from normal pregnancy that has been exposed to either serum of normal pregnancy, EOPE, or LOPE. $(7,27)$

Many of in vitro experiments were done as prelude for translational researches. Cell lines have limitations for preelampsia model due to the difficulties in interpretation to in vivo conditions. Many experiments, such as by Petroff et al(29) found experimental techniques to isolate human trophoblastic cells then cultured as primary trophoblastic cells as an approach for in vivo situation. Successful isolation of cytotrophoblastic cells has been proven to resemble human condition for several placental functions, such endocrinology and immunology functions of the placenta, placental differention, and apoptotic conditions.(26,28-30)

Previously, others have used cultured primary trophoblastic cells given serum of preeclamptic patients as models for preeclampsia condition. Pramatirta (26) found expression of TNF- $\alpha$ and caspase-3,and apoptotic index in preeclampsia serum-induced trophoblast cells were higher than normal and controls. In other studies, they found structural derrangement of vessels resembling disruption in interaction of trophoblastic cells with endothelial cells. $(25,31)$ To conclude, these evidences supported the method of serum preeclampsia treatment in vitro is suitable for preeclampsia model.

The mechanisms responsible for the genesis of the preeclamptic syndrome are poorly understood $(1,7,32)$ although roles for abnormal placentation(3-6), uteroplacental ischemia(5,7-9), endothelial cell dysfunction(10-11), and exaggerated maternal inflammatory response to deported trophoblast $(3-4,33)$ have been proposed.

Peroxisome Proliferator-activated Receptor- $\gamma$ (PPAR- $\gamma$ ) is a member of the nuclear receptor superfamily. Included as transcription factors, they are members of the ligand-activated nuclear hormone receptor superfamily, and play major roles in diverse aspects of energy metabolism, inflammation, and development. Following ligand binding, PPARs form heterodimers with retinoid X receptors (RXRs), and bind to PPAR-response elements (PPREs) of target genes to activate transcription.(34-36)

Three subtypes of PPAR has been identified; PPAR $a, \beta$, and $\gamma .(20-21)$ All three subtypes are expressed in placenta with different levels. PPAR- $\gamma$ has been reported as crucial part of normal placental development as deletion of PPAR-y in mice is $100 \%$ lethal, with no surviving embryos born. Homozygous PPAR-ydeletion mice embryos die due to severe placental dysfunction.(37-38)

Disrupted expression of PPAR-y were implicated in several vital placental functions including regulation of inflammatory reactions that resulted in severe gestational disorders. Effect of PPAR- $\gamma$ in the regulation of pro-inflammatory mediators such as IL-6, IL-8, and TNF- $a$ is important for normal pregnancy to ensue. 
$(20,38)$ Other evidence proofed the involvement of PPAR-y in regulation of throphoblasts functions. Antagonists PPAR-y used in vitro of first trimester extravillous trophoblasts resulted in increase throphoblast invasion, while agonist inhibited it. These data support the role of PPAR- $\gamma$ in the regulation of trophoblasts invasion to decidua. $(21,38)$

Previously studies found PPAR-y was expressed in human placenta.(40-41) PPAR-y mRNA was expressed in term pregnancy.(39) Previously, others have found the primary culture of isolated trophoblasts from first trimester pregnancy expressed PPAR-y. This same research strengthen the possible involvement of PPAR- $y$ in normal pregnancy because they found PPAR- $y$ expression was preserved until third trimester.

In our study we proved the possible involvement of PPAR-y in preeclampsia. We used Western Blot technique to analyze expression of PPAR- $\gamma$ in primary trophoblastic cells treated by serum of normal pregnancy, EOPE, and LOPE. Treatment of the primary trophoblastic cells with LOPE was shown to induce high expression of PPAR-y. Whereas, treatment of trophoblastic cells by EOPE resulted in similar result as treatment by normal pregnancy, with no induction of PPAR-y expression. Handschuh et al.(43) stated PPAR-y activity depend on the trophoblast subpopulation, gestational age, and types of stimulating ligands. Therefore, different content of serum in EOPE and LOPE has different effect to PPAR- $\gamma$ expression..

In LOPE, maternal factors such as obesity, hyperlipidemia, diabetes, chronic hypertension contribute much for emergence of the disease.(44-47) In our experiment the high expression of PPAR-y induced by treatment with serum of LOPE may indicate PPAR-y expression inversely correlates with its activity. As Levistka et al.(48) showed agonist PPAR-y rosiglitazone induced reduction in the receptor expression in the human choriocarcinoma derived cell line BeWo, an established model of synctitiotrophoblast formation in vitro, and primary trophoblast cells. In contrast, inhibition of PPAR-y activity using T0070907 causing extreme enhancement of receptor expression. Thus further study is necessary to proof the PPAR$y$ expression increasement in our study is affected by the protein activity.

Above evidence suggested the activity of PPAR-y is modulated by negative feedback.(48). Similar with Levitska et al.(48) other study by Knabl et al.(49) also stated PPAR-y as transcription factor plays important roles in fat and glucose metabolism, an in cell growth and differentiation, so that thight autoregulation is necessary to even out its activity. A high activity will induce lower expression, while low activity result in high receptor expression.

The mechanism of EOPE in pregnancy was according to the "two-stage theory of preeclampsia". In this theory, in the first stage of disease development, defective trophoblastic invasion result in shallow placentation, and the impair remodeling of muscular layer in spiral arteries causing the spiral arteries unable to fully dilated to supply normal pregnancy development. Further mechanism was at the second stage resulting from failure to establish an adequate uteroplacental blood flow leads to relative hypoxia in trophoblastic tissue, thereby eliciting an oxidative stress response, thus releasing placental debris that in maternal circulation and emerged as symptomatic disease. As a consequence for abnormal 
trophoblastic invasion at early placental development will result in earlier disease manifestation $(<34$ weeks), or EOPE.(44-47) Based on this theory, in EOPE abnormal trophoblast activity may be regulated by PPAR-y, however high activity of this receptor result in diminish receptor expression.(48-49)

\section{Conclusion}

PPAR-y might play role in the pathophysiology of LOPE but not in EOPE. Other possibility is the activity of PPAR- $y$ in EOPE is inversely correlated with the expression, therefore the high enzymatic activity of PPAR$Y$ is tightly regulated by attenuating its expression.

\section{Limitation of the study}

This study is limited by a possible discrepancy among gene expression, protein expression, and protein activity. Gene activities describe transcription process at mRNA level, while protein expression is highly modified at translational process or post translation, as well as protein degradation rate. Protein activity may be affected by chemical reaction, therefore may influence by presence of catalisator or inhibitor. Further research must confirm the mechanism of higher expression of PPAR-y in our research at pre-or post-receptor level.(50)

\section{Abbreviations}

EOPE: Early-onset Preeclampsia

LOPE: Late-onset Preeclampsia

PPAR-y: Peroxisome Proliferator-activated Receptor- $ү$

PPRE: PPAR-response elements

RXR: Retinoid X receptors

\section{Declarations}

\section{Ethics Approval}

The use of the samples for research purposes was approved by the ethical reviews boards of the Health Research Ethics Committee University of Padjadjaran Bandung Indonesia.

Consent to participate was not applicable because in this research used archived biological material.

\section{Consent to publish}

All authors read and approved the final manuscript. 
Availability of data and materials

Availability of data and materials are available upon request to the corresponding author. The cells and serum used as archived biological materials are courtesy from Oncology and Stem Cell Working Group, Faculty of Medicine, Universitas Padjadjaran, Bandung, Indonesia.

\section{Competing Interests}

The author(s) declared no potential conflicts of interest with respect to the research, authorship,and/or publication of this article.

\section{Funding}

This study did not receive financial support from any parties.

\section{Authors' Contributions}

WP, KIM, HBA did the conception and design of the study, acquisition of data, analysis and interpretation of the data, drafting the manuscript and revising the manuscript critically for important intellectual content.

AFK, UAL did the conception and design of the study, acquisition of data, and analysis and interpretation of the data.

AAR drafted the manuscript and revising the manuscript critically for important intellectual content.

\section{Acknowledgments}

Author(s) would like to acknowledge Ronny Lesmana,MD.,PhD and Hanna Goenawan, M.D., PhD as appreciation in technical assistance.

\section{References}

1. Duley L. The global impact of pre-eclampsia and eclampsia.Seminars in perinatology; 2009. Elsevier.

2. Steegers EA, Von Dadelszen P, Duvekot JJ, Pijnenborg R. Pre-eclampsia. The Lancet. 2010;376(9741):631-44.

3. Brosens I, Pijnenborg R, Vercruysse L, Romero R. The "Great Obstetrical Syndromes" are associated with disorders of deep placentation. Am J Obstet Gynecol. 2011;204(3):193-201.

4. Pijnenborg R, Vercruysse L, Brosens I. Deep placentation. Best practice \& research Clinical obstetrics \& gynaecology. 2011;25(3):273-85.

5. Redman C, Sargent I, Staff A. IFPA Senior Award Lecture: making sense of pre-eclampsia-two placental causes of preeclampsia? Placenta. 2014;35:S20-S5. 
6. Yanagisawa M, Kurihara H, Kimura S, Tomobe Y, Kobayashi M, Mitsui Y, dkk. A novel potent vasoconstrictor peptide produced by vascular endothelial cells. Nature. 1988;332(6163):411.

7. Brosens I, Brosens JJ, Muter J, Puttemans P, Benagiano G. Preeclampsia: the role of persistent endothelial cells in uteroplacental arteries. Am J Obstet Gynecol. 2019;S0002-9378(19):30323-0.

8. Burton G, Woods A, Jauniaux E, Kingdom J. Rheological and physiological consequences of conversion of the maternal spiral arteries for uteroplacental blood flow during human pregnancy. Placenta. 2009;30(6):473-82.

9. Myatt L. Role of placenta in preeclampsia. Endocrine. 2002;19(1):103-11.

10. Koopmans CM, Blaauw J, van Pampus MG, Rakhorst G, Aarnoudse JG. Abnormal endotheliumdependent microvascular dilator reactivity in pregnancies complicated by normotensive intrauterine growth restriction. Am J Obstet Gynecol. 2009;200(1):66. e1-. e6.

11. Roberts J. Taylor RN, Musci TJ, Rodgers GM, Hubel CA, McLaughlin MK. Preeclampsia: an endothelial cell disorder Am J Obstet Gynecol. 1989;161:1200-4.

12. Brennan LJ, Morton JS, Davidge ST. Vascular dysfunction in preeclampsia. Microcirculation. 2014;21(1):4-14.

13. Shah DA, Khalil RA. Bioactive factors in uteroplacental and systemic circulation link placental ischemia to generalized vascular dysfunction in hypertensive pregnancy and preeclampsia. Biochem Pharmacol. 2015;95(4):211-26.

14. Ogge G, Chaiworapongsa T, Romero R, Hussein Y, Kusanovic JP, Yeo L, dkk. Placental lesions associated with maternal underperfusion are more frequent in early-onset than in late-onset preeclampsia. J Perinat Med. 2011;39(6):641-52.

15. Raymond D, Peterson E. A critical review of early-onset and late-onset preeclampsia. Obstet Gynecol Surv. 2011;66(8):497-506.

16. Redman CW, Sacks GP, Sargent IL. Preeclampsia: an excessive maternal inflammatory response to pregnancy. Am J Obstet Gynecol. 1999;180(2):499-506.

17. Hernández-Díaz S, Toh S, Cnattingius S. Risk of Preeclampsia in First and Subsequent Pregnancies: Prospective Cohort Study. Obstetric Anesthesia Digest. 2010;30(2):98-9.

18. Stepan H, Unversucht A, Wessel N, Faber R. Predictive value of maternal angiogenic factors in second trimester pregnancies with abnormal uterine perfusion. Hypertension. 2007;49(4):818-24.

19. Wikström A-K, Larsson A, Eriksson UJ, Nash P, Nordén-Lindeberg S, Olovsson M. Placental growth factor and soluble FMS-like tyrosine kinase-1 in early-onset and late-onset preeclampsia. Obstet Gynecol. 2007;109(6):1368-74.

20. Fournier T, Guibourdenche J, Handschuh K, Tsatsaris V, Rauwel B, Davrinche C, dkk. PPARy and human trophoblast differentiation. J Reprod Immunol. 2011;90(1):41-9.

21. McCarthy FP, Delany AC, Kenny LC, Walsh SK. PPAR-y-a possible drug target for complicated pregnancies. Br J Pharmacol. 2013;168(5):1074-85. 
22. Waite LL, Louie RE, Taylor RN. Circulating activators of peroxisome proliferator-activated receptors are reduced in preeclamptic pregnancy. J Clin Endocrinol Metab. 2005;90(2):620-6.

23. Holdsworth-Carson S, Lim R, Mitton A, Whitehead C, Rice G, Permezel M, dkk. Peroxisome proliferator-activated receptors are altered in pathologies of the human placenta: gestational diabetes mellitus, intrauterine growth restriction and preeclampsia. Placenta. 2010;31(3):222-9.

24. Neale D, Demasio K, Illuzi J, Chaiworapongsa T, Romero R, Mor G. Maternal serum of women with pre-eclampsia reduces trophoblast cell viability: evidence for an increased sensitivity to Fasmediated apoptosis. J Matern Fetal Neonatal Med. 2003;13(1):39-44.

25. Levine RJ, Esterlitz JR, Raymond EG, DerSimonian R, Hauth JC, Curet LB, dkk. Trial of Calcium for Preeclampsia Prevention (CPEP): rationale, design, and methods. Control Clin Trials. 1996;17(5):44269.

26. Pramatirta AY, Laksono B, Fauziah PN, Anwar AD, Krisnadi SR, Retnoningrum DS, dkk. Effects of Low Dose Aspirin on Caspase 3, TNF-a and Apoptotic Index Levels in Preclampsia Maternal SerumInduced Placental Trophoblast Cell Line In Vitro. Journal of PharmTech Research. 2016;9(11):47-53.

27. Roberts JM, Gammill HS. Preeclampsia: recent insights. Hypertension. 2005;46(6):1243-9.

28. Orendi K, Kivity V, Sammar M, Grimpel Y, Gonen R, Meiri H, dkk. Placental and trophoblastic in vitro models to study preventive and therapeutic agents for preeclampsia. Placenta. 2011;32:S49-S54.

29. Petroff MG, Phillips TA, Ka H, Pace JL, Hunt JS. Isolation and culture of term human trophoblast cells. Placenta and Trophoblast. Edisi: Springer; 2006. h. 203-17.

30. Li L, Schust DJ. Isolation, purification and in vitro differentiation of cytotrophoblast cells from human term placenta. Reprod Biol Endocrinol. 2015;13(1):71.

31. Kalkunte S, Boij R, Norris W, Friedman J, Lai Z, Kurtis J, dkk. Sera from preeclampsia patients elicit symptoms of human disease in mice and provide a basis for an in vitro predictive assay. Am J Pathol. 2010;177(5):2387-98.

32. Davison JM, Homuth V, Jeyabalan A, Conrad KP, Karumanchi SA, Quaggin S, dkk. New aspects in the pathophysiology of preeclampsia. J Am Soc Nephrol. 2004;15(9):2440-8.

33. Bulla R, Agostinis C, Bossi F, Rizzi L, Debeus A, Tripodo C, dkk. Decidual endothelial cells express surface-bound $\mathrm{C} 1 \mathrm{q}$ as a molecular bridge between endovascular trophoblast and decidual endothelium. Mol Immunol. 2008;45(9):2629-40.

34. Bright JJ, Kanakasabai S, Chearwae W, Chakraborty S. PPAR regulation of inflammatory signaling in CNS diseases. PPAR research. 2008;2008.

35. Lehrke M, Lazar MA. The many faces of PPARy. Cell. 2005;123(6):993-9.

36. Parast MM, Yu H, Ciric A, Salata MW, Davis V, Milstone DS. PPARy regulates trophoblast proliferation and promotes labyrinthine trilineage differentiation. PLoS One. 2009;4(11):e8055. 
37. Giaginis C, Spanopoulou E, Theocharis S. PPAR-y signaling pathway in placental development and function: A potential therapeutic target in the treatment of gestational diseases. Expert Opin Ther Targets. 2008;12(8):1049-63.

38. Kadam L, Kohan-Ghadr HR, Drewlo S. The balancing act-PPAR- $\gamma$ 's roles at the maternal-fetal interface. Syst Biol Reprod Med. 2015;61(2):65-71.

39. Marvin K, Eykholt R, Keelan J, Sato T, Mitchell M. The 15-Deoxy- $\Delta 12$, 14-prostaglandin J2Receptor, Peroxisome Proliferator Activated Receptor-y (PPARY) is Expressed in Human Gestational Tissues and is Functionally Active in JEG3 Choriocarcinoma Cells. Placenta. 2000;21(4):436-40.

40. Rodie VA, Young A, Jordan F, Sattar N, Greer IA, Freeman D. Human placental peroxisome proliferatoractivated receptor $\delta$ and $y$ expression in healthy pregnancy and in preeclampsia and intrauterine growth restriction. J Soc Gynecol Investig. 2005;12(5):320-9.

41. Wang Q, Fujii H, Knipp G. Expression of PPAR and RXR isoforms in the developing rat and human term placentas. Placenta. 2002;23(8-9):661-71.

42. Fournier T, Pavan L, Tarrade A, Schoonjans K, Auwerx J, ROCHETTE-EGLY C, dkk. The Role of PPARY/RXR-a Heterodimers in the Regulation of Human Trophoblast Invasion. Ann N Y Acad Sci. 2002;973(1):26-30.

43. Handschuh K, Guibourdenche J, Cocquebert M, Tsatsaris V, Vidaud M, Evain-Brion D, dkk. Expression and regulation by PPARy of hCG a-and $\beta$-subunits: comparison between villous and invasive extravillous trophoblastic cells. Placenta. 2009;30(12):1016-22.

44. Aksornphusitaphong A, Phupong V. Risk factors of early and late onset pre-eclampsia. J Obstet Gynaecol Res. 2013;39(3):627-31.

45. Huppertz B. Placental origins of preeclampsia: challenging the current hypothesis. Hypertension. 2008;51(4):970-5.

46. Roberts JM, Escudero C. The placenta in preeclampsia. Preg Hypertension: An Int J Women's Cardiovasc Health. 2012;2(2):72-83.

47. Wang A, Rana S, Karumanchi SA. Preeclampsia: the role of angiogenic factors in its pathogenesis. Physiology. 2009;24(3):147-58.

48. Levytska K, Drewlo S, Baczyk D. PPAR-y regulates trophoblast differentiation in the BeWo cell model. PPAR research. 2014;2014.

49. Knabl J, Hüttenbrenner R, Hutter S, Günthner-Biller M, Vrekoussis T, Karl K, dkk. Peroxisome proliferator-activated receptor-gamma (PPARY) is down regulated in trophoblast cells of gestational diabetes mellitus (GDM) and in trophoblast tumour cells BeWo in vitro after stimulation with PPARY agonists. J Perinat Med. 2014;42(2):179-87.

50. del Bas JM, Laos S, Caimari A, Crescenti A, Arola L. Detection of bioavailable peroxisome proliferatoractivated receptor gamma modulators by a cell-based luciferase reporter system. Anal Biochem. 2012;427(2):187-9.

\section{Figures}




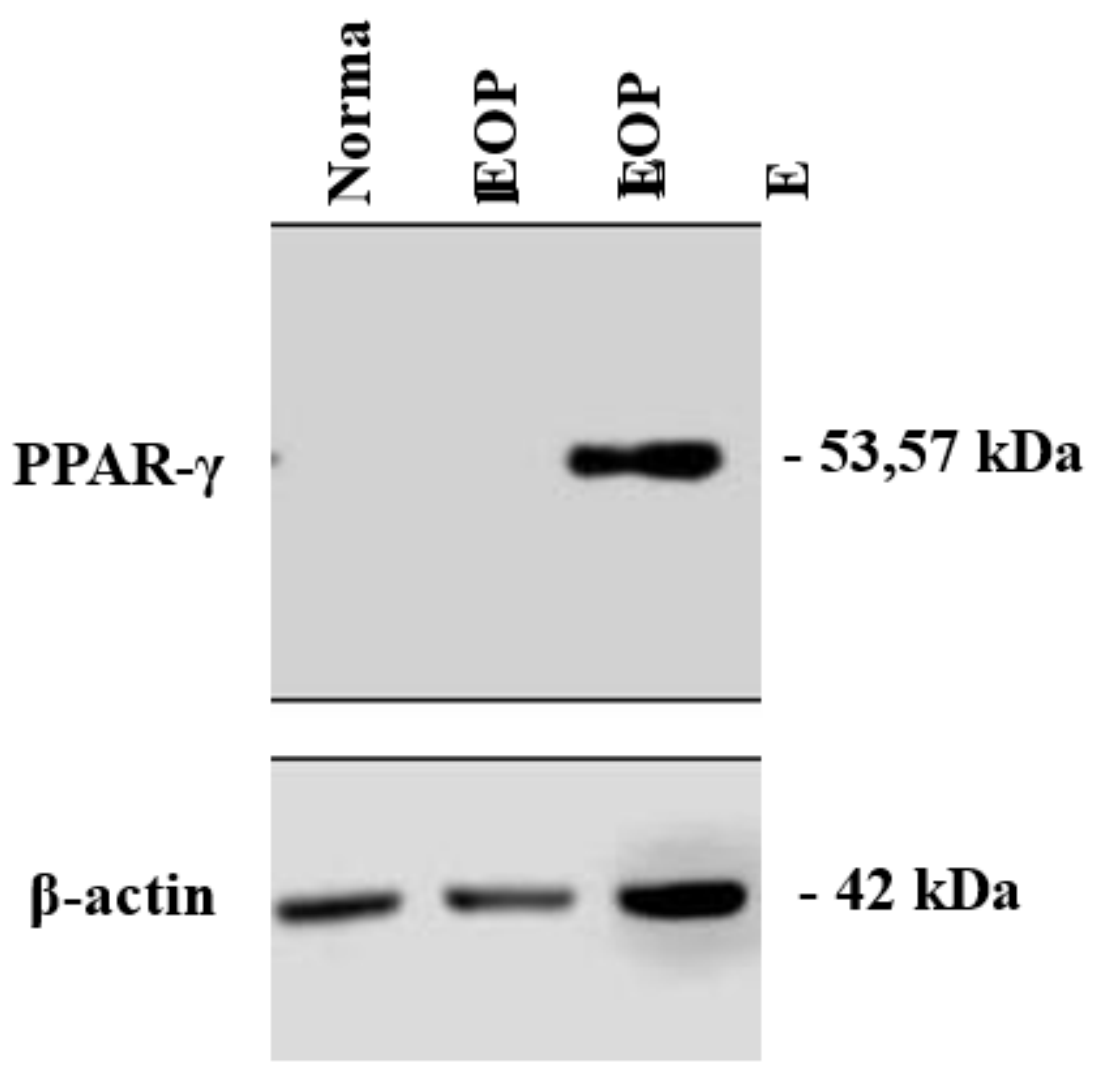

Figure 1

Expression of PPAR-y. Primary trophoblastic cells were treated with normal serum (normal), EOPE, and LOPE. PPAR-y proteins were subjected to immunoblot analysis with a mAb that recognizes PPAR-y as well as with a $\mathrm{mAb}$ to $\beta$-actin (loading control). 


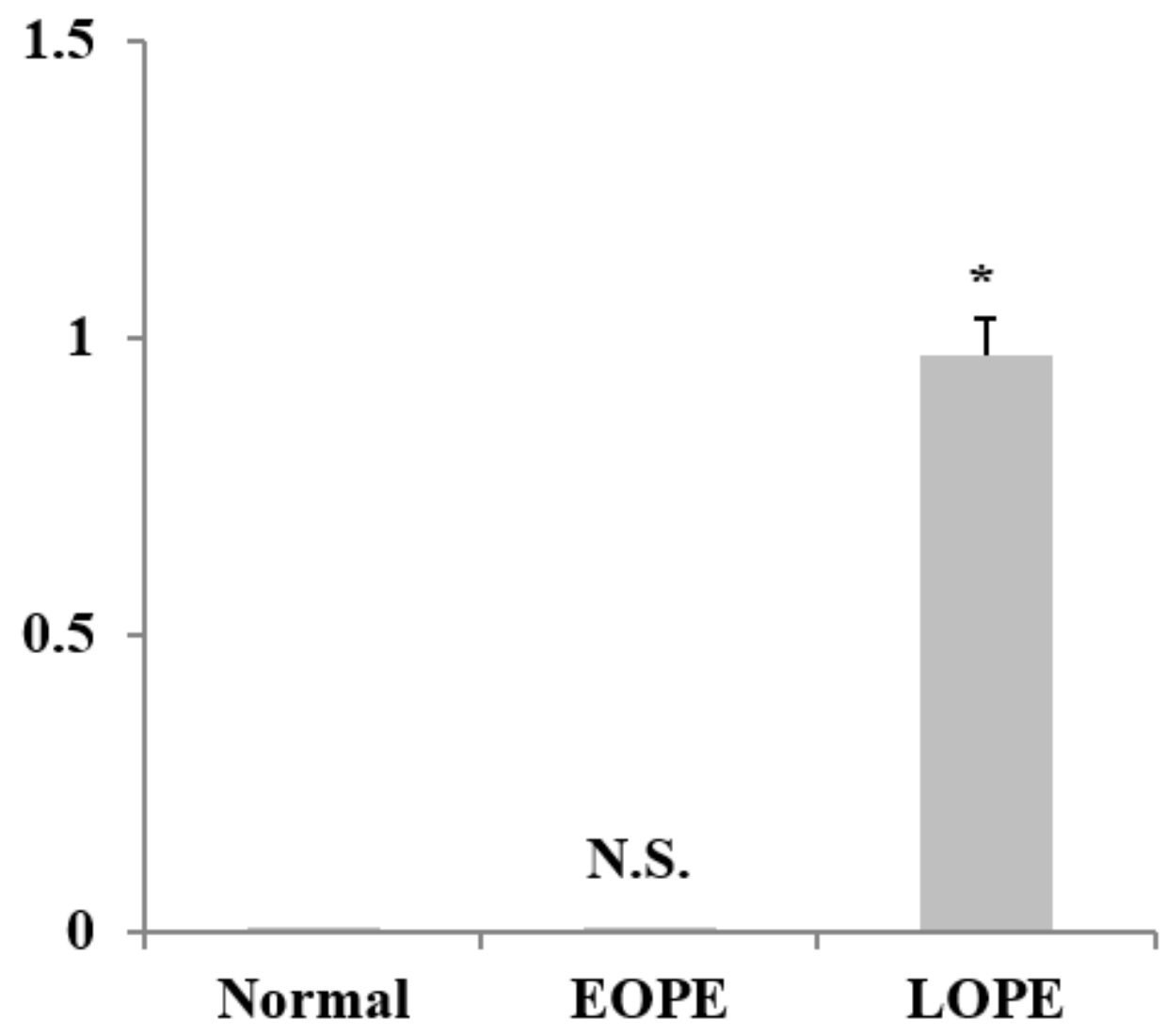

Figure 2

Quantification of Expression of PPAR-y. Expression was quantified by densitometry scanning by Image-J followed by normalizing PPAR- $\gamma$ expression to that of $\beta$-actin. Data are the means $\pm S$.E. from three separate experiments. versus serum normal pregnancy. ${ }^{*} p<0.01$ (one-way ANOVA and Bonferroni's test) versus normal pregnancy. N.S., non significant. 